\title{
Relations between rhizobial nodulation and root colonization of Acacia crassicarpa provenances by an arbuscular mycorrhizal fungus, Glomus intraradices Schenk and Smith or an ectomycorrhizal fungus, Pisolithus tinctorius Coker \& Couch
}

\author{
Didier LESUEUR $^{\mathrm{a}, \mathrm{b}}$, Robin DUPONNOIS ${ }^{\mathrm{c}, \mathrm{d} *}$ \\ a Forest Department of CIRAD, UPR 80, Laboratoire Commun de Microbiologie (IRD/UCAD/ISRA), Centre de Bel Air, BP 1386, Dakar, Senegal \\ b Present address: Forest Department of CIRAD, UPR 80, Tropical Soil Biology and Fertility Institute of CIAT (TSBF/CIAT), \\ World Agroforestry Centre, PO Box 30677, Nairobi, Kenya \\ c UMR 113 IRD/CIRAD/AGRO-M/UM2 USC INRA 1242, Laboratoire des Symbioses Tropicales et Méditerranéennes (LSTM), \\ Campus International de Baillarguet, 34398 Montpellier, France \\ d Present address: IRD, 01 BP 182, Ouagadougou, Burkina Faso
}

(Received 8 April 2004; accepted 12 April 2005)

\begin{abstract}
The present study was initiated to (i) determine the ability of an ectomycorrhizal and an arbuscular mycorrhizal symbiont to colonize three provenances of Acacia crassicarpa root systems, (ii) to examine plant growth response to the mycorrhizal inoculation and (iii) to measure their influence on the rhizobial symbiosis with a Bradyrhizobium isolate. This study has been performed with 2 fungal symbionts: Glomus intraradices, an Arbuscular Mycorrhizal fungus, and an ectomycorrhizal fungus Pisolithus tinctorius strain GEMAS. Two experiments have been performed during two different climatic periods, hot season $\left(30^{\circ} \mathrm{C}\right.$ day, $20^{\circ} \mathrm{C}$ night, June to October) for ectomycorrhizal inoculation and cold season $\left(25^{\circ} \mathrm{C}\right.$ day, $15{ }^{\circ} \mathrm{C}$ night, November to March) for endomycorrhizal inoculation. Moreover, Bradyrhizobium sp. strain Aus $13 \mathrm{C}$ has been co-inoculated with each of these fungal symbionts. The results showed that ectomycorrhizal and AM fungal symbiosis clearly benefit to the growth of $A$. crassicarpa provenances and these fungal symbioses greatly improve the rhizobial nodulation process. However, some differences of growth were observed between the provenances tested and our results showed that both Papua New Guinea provenances produced more important total biomass than the provenance from Madagascar in both experiments However, no significant differences were observed in terms of nodulation and mycorrhization. Further research must be undertaken to identify the convenient ecological characteristics in which each kind of mycorrhizal symbiosis exerts the best effect on plant growth and nodulation formation and to identify in such environmental conditions the better rhizobial/mycorrhizal symbiosis combination.
\end{abstract}

Acacia crassicarpa / arbuscular mycorrhizas / ectomycorrhizas / rhizobium

Résumé - Relations entre la nodulation induite par un rhizobium et la colonisation des racines de plusieurs provenances d'Acacia crassicarpa par un champignon mycorhizien arbusculaire Glomus intraradices Schenk and Smith ou par un champignon ectomycorhizien, Pisolithus tinctorius Coker \& Couch. La présente étude a été initiée pour (i) déterminer l'aptitude de champignons mycorhiziens (ectomycorhizes et champignons arbusculaires) à coloniser le système racinaire de 3 provenances d'Acacia crassicarpa, (ii) d'évaluer la réponse de la plante à l'inoculation avec des champignons mycorhizes en termes de croissance et (iii) de mesurer leur influence sur la symbiose fixatrice d'azote avec une souche de Bradyrhizobium. Cette étude a été réalisée avec 2 symbiotes fongiques: Glomus intraradices, un champignon mycorhizien arbusculaire, et un champignon ectomycorhizien, Pisolithus tinctorius souche GEMAS. Deux experiences ont été réaliséees durant 2 periodes climatiques differentes, saison chaude $\left(30^{\circ} \mathrm{C}\right.$ jour, $20^{\circ} \mathrm{C}$ nuit, juin à octobre $)$ pour l'inoculation avec le champignon ectomycorhizien, et saison froide $\left(25^{\circ} \mathrm{C}\right.$ jour, $15^{\circ} \mathrm{C}$ nuit, novembre à mars) pour l'inoculation avec le champignon endomycorhizien. La souche de Bradyrhizobium sp. strain Aus13C a été co-inoculée avec chacun de ces symbiontes fongiques. Les résultats ont montré que les symbioses ecto and endomycorhiziennes améliorent clairement la croissance des plantes des 3 provenances d'Acacia crassicarpa et qu'elles ont un effet très positif sur la nodulation des plantes par la souche de rhizobium. Cependant, des différences de croissance ont été observées entre les différentes provenances testées et nos résultats ont montré que dans les deux experiences, les deux provenances originaires de Papouasie-Nouvelle Guinée produisent plus de biomasse que la provenance originaire de Madagascar. Cependant, aucune différence significative n'a été observée en termes de nodulation et de mycorrhization. Des recherches ultérieures devront être entreprises pour identifier les conditions écologiques les plus appropriées dans lesquelles chaque type de symbioses mycorhiziennes exercera son meilleur effet sur la croissance de la plante ainsi que sur sa nodulation, et pour identifier les conditions environnementales les plus favorables à une symbiose mixte mycorhizes/rhizobium.

Acacia crassicarpa / champignons mycorhiziens arbusculaires / ectomycorhizes / rhizobium

\footnotetext{
* Corresponding author: Robin.Duponnois@ird.bf
} 


\section{INTRODUCTION}

During recent decades, dramatic deforestation has occurred in West Africa following excessive industrial exploitation, clearing for agricultural purposes and collection of firewood. In order to rehabilitate these degraded areas, a lot of reforestation programs have been attempted to restore sustainable ecosystems [20]. Among the most useful plants in the Soudano Sahelian areas, Acacia is the largest mimosoid genus and includes nearly 1200 species [28]. Their positive impacts on the soil, erosion and local economies are well documented [7, 19]. Inside the genus Acacia, fast-growing trees, brought from Australia and introduced in West Africa, have been evaluated by the plant growth in field trials $[5,7,8,24]$. Their associated rhizobial symbioses allow these tree species to grow in nitrogen-deficient soils frequently encountered in tropical areas and the continuous replacement of their leaves and roots ensures transfer of nitrogen to the soil [29]. As with many $\mathrm{N}_{2}$-fixing trees and shrubs, Acacia is very dependent on mycorrhizas for the absorption of nutrients (in particular $\mathrm{P}$ assimilation) required for their growth and efficient $\mathrm{N}_{2}$ fixation $[2,4,13,33]$. As most of Australian native plants (Eucalyptus, Casuarina, etc.), Acacia may form mycorrhizal associations with arbuscular mycorrhizas (AM) and ectomycorrhizas (EM) [1, 6, 12]. More recently, it has been established that each morphological types of mycorrhizas could greatly interact within the same root system [15]. All these studies have indicated the functional compatibility of both partners and a lot of informations are available on the mycorrhizal requirements of Acacia and their growth responses to inoculation with ecto and/or endomycorrhizal fungi in experimental conditions [8, 10, 12, 14]. However, as these forms of mycorrhizal symbiosis are differently efficient at using soil nutrient contents such as organic nitrogen [27], it is important to evaluate the host plant dependencies for ecto or endomycorrhizal symbiosis in order to predict the impact of controlled mycorrhization on the plant growth and on nutrient soil fertility.

A. crassicarpa is one of the fastest-growing of the tropical acacias. A total above-ground biomass of 207 dry $\mathrm{t} / \mathrm{ha}$ at 3 years was recorded for a Papua New Guinea provenance in Thailand [36]. In Sabah/Malaysia, A. crassicarpa trees have attained a mean height outperforming Acacia mangium and Acacia auriculiformis [34]. A. crassicarpa tolerates a wide range of infertiles soils, salt winds, fire and grass competition and is described has having a potential for industrial plantations [9]. In 2000 , over 40000 ha of plantation of this specie have been established in the Island of Sumatra in Indonesia [26]. In 2004, we estimated around 100000 ha the surface planted with $A$. crassicarpa in Indonesia and it should reach more than 500000 ha in the five next years (Jean-Pierre Bouillet, personal communication). This species is found in warm to hot, humid and sub-humid climates in the lowland tropics (mean max of hottest month is $32-34{ }^{\circ} \mathrm{C}$ and mean minimum of the coldest is $12-21^{\circ} \mathrm{C}$ ). Regarding wood characteristics, it is dense suitable for burning and strong too. Pulp properties also are promising [9]. Significant provenance variation is reported. Papua New Guinea provenances have consistently grown faster than Queensland sources in trials in Australia, China and Thailand [21]. Few informations are available on the symbiotic requirements of A. crassicarpa. Dommergues et al. [8] indicated that A. crassicarpa is usually described as being always nodulated in soils from their origin area but also in the countries where it was introduced successfully. However, Doran and Turnbull [9] recommend the inoculation of nursery seedlings with a selected strain of rhizobia. Concerning the functional compatibility between provenances of $A$. crassicarpa and arbuscular mycorrhizal fungi or ectomycorrhizal, as well as the interactions between rhizobial and mycorrhizal symbiosis, there are still largely unknown.

The present study was initiated to (i) determine the ability of an ectomycorrhizal and an arbuscular mycorrhizal symbiont to colonize three provenances of Acacia crassicarpa root systems, (ii) to examine the three provenances response to the mycorrhizal inoculation and (iii) to measure their influence on the rhizobial symbiosis with a Bradyrhizobium isolate.

\section{MATERIALS AND METHODS}

\subsection{Host plant}

The geographical origins of the A. crassicarpa provenances are indicated in Table I. Seeds of A. crassicarpa were surface-sterilized with concentrated sulphuric acid $(36 \mathrm{~N})$ for $60 \mathrm{~min}$. The acid solution was then decanted off and the seeds rinsed and imbibed for $12 \mathrm{~h}$ in 4 changes of sterile distilled water. Seeds were then transferred aseptically in Petri dishes filled with $1 \%(\mathrm{w}: \mathrm{v})$ water agar medium. These plates were incubated for 4 days at $25^{\circ} \mathrm{C}$ in the dark. The germinating seeds were used when rootlets were $1-2 \mathrm{~cm}$ long.

\subsection{Rhizobial and fungal inocula}

The isolate of Bradyrhizobium Aust 13C has been isolated from nodules collected in a forest plantation of A. mangium in Australia (Queensland, $16^{\circ} 15^{\prime} \mathrm{S}, 145^{\circ} 20^{\prime} \mathrm{E}$ ) [18]. It is very effective with Acacia mangium into several field trials set up all around the world [16-18], and it was identified as forming an efficient nitrogen-fixing symbiosis with A. crassicarpa in vitro and under nursery conditions (Antoine Galiana, personal communication). It was cultured in glass flasks containing liquid yeast extract - mannitol medium [35] at $37{ }^{\circ} \mathrm{C}$ for 5 days on an orbital shaker. The bacterial suspensions were approximately $10^{9}$ cells $\mathrm{mL}^{-1}$.

Table I. Geographical origins of A. crassicarpa provenances.

\begin{tabular}{lcccc}
\hline Provenance & Seeddlot & Region & Seed collection site & Altitude (m) \\
\hline P1 & $89 / 08809 \mathrm{~N}$ & Papua New Guinea & $141^{\circ} 55^{\prime} \mathrm{E}, 8^{\circ} 36^{\prime} \mathrm{S}$ & 25 \\
P2 & $89 / 08829 \mathrm{~N}$ & Papua New Guinea & $141^{\circ} 55^{\prime} \mathrm{E}, 8^{\circ} 36^{\prime} \mathrm{S}$ & 25 \\
P3 & $99 / 10485 \mathrm{~N}$ & Madagascar & $48^{\circ} 55^{\prime} \mathrm{E}, 18^{\circ} 57^{\prime} \mathrm{S}$ & 30 \\
\hline
\end{tabular}


The arbuscular mycorrhizal fungus Glomus intraradices Schenck \& Smith (DAOM 181602, Ottawa Agricultural Herbarium) was propagated on leek (Allium porrum L.) for 12 weeks in greenhouse on Terragreen $^{\mathrm{TM}}$ substrate. This calcined clay (particule size average $5 \mathrm{~mm}$ ), Oil-Dri US-special Ty/IIIR (Oil-Dri Company, Chicago, USA) is an attapulgite from Georgia used as substrate for propagation of mycorrhizal fungi [31]. This fungal isolate is very effective with another fastgrowing Australian acacia, Acacia holosericeae [12]. Before inoculation, the leek plants were uprooted, gently washed with tap water and roots cut into segments $0.5 \mathrm{~cm}$ long bearing around 250 vesicles $\mathrm{cm}^{-1}$. Non-mycorrhizal leek roots, prepared as above, were used for the control treatment without endomycorrhizal inoculation.

The ectomycorrhizal fungus Pisolithus tinctorius (Pers.) Coker \& Couch strain GEMAS was isolated from a sporocarp collected under a monospecific forest plantation of A. mangium in Malaysia. It was routinely maintained in Petri dishes on MMN agar medium at $25^{\circ} \mathrm{C}$ [25]. This fungal strain significantly increased the growth of an Australian Acacia species, A. holosericea, in a previous experiment [12].

Fungal inoculum was prepared in $1.6 \mathrm{~L}$ glass jars containing $1.3 \mathrm{~L}$ vermiculite-peat mixture $(4 / 1 ; \mathrm{v} / \mathrm{v})$ and autoclaved for $20 \mathrm{~min}$ at $120^{\circ} \mathrm{C}$. The substrate was then moistened to field capacity with $300 \mathrm{~mL}$ liquid MMN medium. The jars were sealed and autoclaved at $120^{\circ} \mathrm{C}$ for $20 \mathrm{~min}$. After cooling, the substrate was then inoculated aseptically with fungal plugs taken from the margin of the fungal colonies and incubated for 6 weeks at $28^{\circ} \mathrm{C}$ in the dark [11].

\subsection{Glasshouse experiment}

Seedlings of A. crassicarpa provenances were grown in $1 \mathrm{dm}^{3}$ pots filled with an autoclaved sandy soil $\left(140{ }^{\circ} \mathrm{C}, 40 \mathrm{~min}\right)$ sampled from a 17 -year-old plantation of $A$. holosericea at Sangalkam $(50 \mathrm{~km}$ from Dakar). Its physicochemical characteristics were as follows: $3.6 \%$ clay, $1.6 \%$ silt, $2.9 \%$ unrefined silt, $51 \%$ sand, $40.9 \%$ unrefined sand, $0.43 \%$ organic matter, $0.25 \%$, organic carbon $5.15 \mathrm{ppm}$ of phosphate, $0.21 \%$ o total nitrogen, $\mathrm{C} / \mathrm{N}$ of $11.9, \mathrm{pH}_{\mathrm{H} 2 \mathrm{O}} 5.7$ ). For ectomycorrhizal inoculation, the soil was mixed with $10 \%(\mathrm{v} / \mathrm{v})$ fungal inoculum or $10 \%$ moistened (MMN medium) vermiculite-peat mixture $(4 / 1 ; \mathrm{v} / \mathrm{v})$ for the treatment without fungus. For endomycorrhizal inoculation, one hole $(1 \mathrm{~cm} \times 5 \mathrm{~cm})$ was made in each pot and filled with $1 \mathrm{~g}$ fresh leek root (mycorrhizal or not for the control without fungus). The holes were then covered with the same autoclaved soil. These experiments have been performed during two different climatic periods, hot season $\left(30{ }^{\circ} \mathrm{C}\right.$ day, $20^{\circ} \mathrm{C}$ night, June to October) for ectomycorrhizal inoculation and cold season $\left(25^{\circ} \mathrm{C}\right.$ day, $15^{\circ} \mathrm{C}$ night, November to March) for endomycorrhizal inoculation.

The plants were placed in a glasshouse and watered twice a week without fertiliser addition. After 1-week culture, the young seedlings were inoculated by $5 \mathrm{~mL}$ of the Bradyrhizobium sp. suspension $\left(10^{9}\right.$ bacterial cells) or $5 \mathrm{~mL}$ of the culture medium without bacteria for the control treatments as it was suggested by Diouf et al. (2003) [6] for the inoculation of Acacia mangium. The pots were arranged in a randomised complete block design with nine replicates per treatment.

After 5 months culture, Acacia plants were uprooted and the root systems gently washed. The oven-dried $\left(1\right.$ week at $\left.65^{\circ} \mathrm{C}\right)$ weight of the shoots was measured. After drying, a sub-sample of leaf tissue was ground, ashed $\left(500{ }^{\circ} \mathrm{C}\right)$, digested in $2 \mathrm{~mL} \mathrm{HCl} 6 \mathrm{~N}$ and $10 \mathrm{~mL} \mathrm{HNO}_{3}$ and then analysed by colorimetry for $\mathrm{P}$ [22] and by flame emission for $\mathrm{K}$. Another sub-sample of leaf tissue was ground and digested in $15 \mathrm{~mL} \mathrm{H}_{2} \mathrm{SO}_{4} 36 \mathrm{~N}$ containing $50 \mathrm{~g} \mathrm{~L}^{-1}$ salicylic acid for $\mathrm{N}$ (Kjeldhal) determination. Root nodules were counted and weighed ( 1 week at $65^{\circ} \mathrm{C}$ ). Then entire root systems of each plant were cut into $1 \mathrm{~cm}$ root pieces and mixed. For the ectomycorrhizal treatments, roots with a fungal sheath, randomly chosen in each root samples, were free-hand sectioned, stained with $0.25 \%$ Congo red and observed under a light microscope. Then the ectomycorrhizal colonization (number of ecto- mycorrhizal roots/total number of roots $\times 100$ ) was determined under a stereomicroscope at $\times 40$ magnification on a random sample of at least 100 short roots per root systems. For the internal colonization of arbuscular mycorrhizal fungus, roots fragments were cleared with a $\mathrm{KOH}$ solution $(10 \%, \mathrm{v} / \mathrm{v})$ and stained according to the method of Phillips and Hayman [30]. The roots were placed on a slide for microscopic observation $(\times 250$ magnification) [3]. The endomycorrhizal colonization (length of root fragments with visible mycorrhizal structures/ total length of root fragments) was determined on a random sample of at least fifty $1-\mathrm{cm}$ root pieces per plant. Then these root fragments used to estimate mycorrhizal colonization were oven dried $\left(60^{\circ} \mathrm{C}\right.$, 1 week) and weighed.

Then all data were subjected to one-way analysis of variance and mean values were compared using Newman-Keuls multiple range test $(P<0.05)$. Mycorrhizal rates were Arc sinsqrt $(\mathrm{x})$ transformed before statistical analysis.

\section{RESULTS}

\subsection{Ectomycorrhizal inoculation}

The fungal strain $P$. tinctorius GEMAS was able to form typical ectomycorrhizae with all $A$. crassicarpa provenances after 5 months of growth. The color of ectomycorrhizae was yellow and their morphology varied from simple to branched as it has been previously observed with the ectomycorrhizal symbiosis between P. albus COI007 and A. mangium [10]. Cross section showed a Hartig net whose penetration did not exceed the epidermal cells.

Inoculation with Bradyrhizobium Aust 13C significantly increased shoot growth of all provenances but this positive effect was lower than that recorded with $P$. tinctorius for P1 and P2 (Tab. II). When both were co-inoculated, shoot dry weight was significantly increased over the single inoculation treatments (Tab. II). For the root biomass, Bradyrhizobium Aust $13 \mathrm{C}$ and $P$. tinctorius exerted a significant positive effect for all the provenances without significant differences between each single microbial treatment. The dually inoculation did not exert a higher stimulation than that of the singly inoculations, except for P2 provenance (Tab. II).

For all the provenances, ectomycorrhizal colonization ranged from $40.4 \%$ ( $\mathrm{P} 1$ provenance) to $49.4 \%$ ( $\mathrm{P} 2$ provenance). It was significantly lower when $P$. tinctorius was inoculated alone compared to that recorded in the dually treatments (Tab. III).

Even in the treatments without Bradyrhizobium Aust 13C and despite of the soil autoclaved and the disinfection of seed surface, some nodules were observed along the root systems of A. crassicarpa seedlings for all the provenances. For Aust 13C treatments, the number and the total dry weight of nodules per plant were significantly higher in the treatments with $P$. tinctorius than those found in the treatments without fungal inoculation (Tab. III).

Bradyrhizobial inoculation enhanced leaf nitrogen content for $\mathrm{P} 2$ and $\mathrm{P} 3$ provenances, leaf phosphorus and potassium contents for $\mathrm{P} 3$ provenance (Tab. IV). These leaf mineral contents were increased for all provenances after ectomycorrhizal inoculation. When both symbionts were inoculated, highest values were recorded except for leaf $\mathrm{K}$ content with $\mathrm{P} 1$ provenance (Tab. IV). 
Table I. Effect of the rhizobial and/or ectomycorrhizal inoculations on plant growth of A. crassicarpa provenances after 5-month culture.

\begin{tabular}{|c|c|c|c|c|}
\hline Provenances & Treatments & Shoot Biomass (mg dry weight) & Root biomass (mg dry weight) & Total biomass (mg dry weight) \\
\hline \multirow[t]{4}{*}{$\overline{\mathrm{P} 1}$} & Not inoculated & $1074 \mathrm{a}^{1}$ & $221 \mathrm{a}$ & $1296 \mathrm{a}$ \\
\hline & Aust $13 \mathrm{C}$ & $1776 \mathrm{~b}$ & $407 \mathrm{~b}$ & $2184 \mathrm{~b}$ \\
\hline & P. tinctorius & $2724 \mathrm{c}$ & $470 \mathrm{~b}$ & $3194 \mathrm{c}$ \\
\hline & P. tinctorius + Aust $13 \mathrm{C}$ & $3884 \mathrm{~d}$ & $490 \mathrm{~b}$ & $4374 \mathrm{~d}$ \\
\hline \multirow[t]{4}{*}{$\mathrm{P} 2$} & Not inoculated & $508 \mathrm{a}$ & $142 \mathrm{a}$ & $650 \mathrm{a}$ \\
\hline & Aust $13 \mathrm{C}$ & $1396 \mathrm{~b}$ & $269 \mathrm{~b}$ & $1664 \mathrm{~b}$ \\
\hline & P. tinctorius & $2211 \mathrm{c}$ & $298 \mathrm{~b}$ & $2509 \mathrm{c}$ \\
\hline & P. tinctorius + Aust 13C & $3884 \mathrm{~d}$ & $490 \mathrm{c}$ & $4374 \mathrm{~d}$ \\
\hline \multirow[t]{4}{*}{ P3 } & Not inoculated & $844 \mathrm{a}$ & $191 \mathrm{a}$ & $1035 \mathrm{a}$ \\
\hline & Aust $13 \mathrm{C}$ & $1979 \mathrm{~b}$ & $367 \mathrm{~b}$ & $2346 \mathrm{~b}$ \\
\hline & P. tinctorius & $2370 \mathrm{~b}$ & $385 \mathrm{~b}$ & $2798 \mathrm{~b}$ \\
\hline & P. tinctorius + Aust $13 \mathrm{C}$ & $3187 \mathrm{c}$ & $428 \mathrm{~b}$ & $3572 \mathrm{c}$ \\
\hline
\end{tabular}

${ }^{1}$ For each provenance, data in the same column followed by the same letter are not significantly different according to the one way analysis of variance $(P<0.05)$.

Table II. Effect of microbial inoculation on ectomycorrhizal establishment and on rhizobial symbiosis after 5-month culture.

\begin{tabular}{|c|c|c|c|c|}
\hline Provenances & Treatments & Ectomycorrhizal colonization (\%) & Number of nodules per plant & Nodule dry weight (mg/plant) \\
\hline \multirow[t]{4}{*}{$\overline{\mathrm{P} 1}$} & Not inoculated & $0 \mathrm{a}^{1}$ & $6 \mathrm{a}$ & $14 \mathrm{a}$ \\
\hline & Aust $13 \mathrm{C}$ & $0 \mathrm{a}$ & $31.1 \mathrm{a}$ & $34 \mathrm{a}$ \\
\hline & P. tinctorius & $40.4 \mathrm{~b}$ & $36.7 \mathrm{a}$ & $77 \mathrm{~b}$ \\
\hline & P. tinctorius + Aust $13 \mathrm{C}$ & $61.2 \mathrm{c}$ & $90.6 \mathrm{~b}$ & $85 \mathrm{~b}$ \\
\hline \multirow[t]{4}{*}{$\mathrm{P} 2$} & Not inoculated & $0 \mathrm{a}$ & $0 \mathrm{a}$ & $0 \mathrm{a}$ \\
\hline & Aust $13 \mathrm{C}$ & $0 \mathrm{a}$ & $19.7 \mathrm{ab}$ & $16 \mathrm{a}$ \\
\hline & P. tinctorius & $49.4 \mathrm{~b}$ & $24.9 \mathrm{~b}$ & $69 \mathrm{~b}$ \\
\hline & P. tinctorius + Aust $13 \mathrm{C}$ & $74.6 \mathrm{c}$ & $87 \mathrm{c}$ & $77 \mathrm{~b}$ \\
\hline \multirow[t]{4}{*}{ P3 } & Not inoculated & $0 \mathrm{a}$ & $8.6 \mathrm{a}$ & $15 \mathrm{a}$ \\
\hline & Aust $13 \mathrm{C}$ & $0 \mathrm{a}$ & $35.3 \mathrm{~b}$ & $43 \mathrm{~b}$ \\
\hline & P. tinctorius & $46.4 \mathrm{~b}$ & $42.9 \mathrm{~b}$ & $71 \mathrm{bc}$ \\
\hline & P. tinctorius + Aust $13 \mathrm{C}$ & $66.8 \mathrm{c}$ & $78.8 \mathrm{c}$ & $92 \mathrm{c}$ \\
\hline
\end{tabular}

${ }^{1}$ For each provenance, data in the same column followed by the same letter are not significantly different according to the one way analysis of variance $(P<0.05)$.

\subsection{Arbuscular mycorrhizal fungal inoculation}

In this experiment, Bradyrhizobium Aust 13C inoculation stimulated greatly the P3 provenance shoot and root growth (Tab. V) such as in the previous experiment. In contrast, the AM fungus, $G$. intraradices, had a positive effect on the root and shoot biomass with all the provenances. The dually inoculation did not modified the fungal effect on the plant growth except with P1 provenance where plant growth was decreased compared to that recorded in the G. intraradices treatment and with P2 provenance for the root growth (Tab. V).

The endomycorrhizal colonization ranged from $34.3 \%$ (P1 provenance) to $61.7 \%$ ( $\mathrm{P} 3$ provenance). It was not affected by the Aust 13C inoculation for all the provenances (Tab. VI). No nodules were observed in the control or when Aust $13 \mathrm{C}$ was inoculated alone. On the contrary, the formation of nodules was recorded along root systems of endomycorrhizal seedlings (Tab. VI). The number of nodules was significantly higher with $\mathrm{P} 3$ provenance when Aust 13C was co-inoculated with $G$. intraradices whereas the same bacterial effect was recorded with nodule biomass for $\mathrm{P} 2$ provenance (Tab. VI).

Aust $13 \mathrm{C}$ inoculant only increased leaf mineral contents for P3 provenance whereas $G$. intraradices inoculation significantly enhanced leaf $\mathrm{P}, \mathrm{N}$ and $\mathrm{K}$ contents for all the provenances (Tab. VII). Compared to the G. intraradices treatment, the dual inoculation involved a depletion of $\mathrm{P}$ and $\mathrm{K}$ contents for $\mathrm{P} 1$ provenance seedlings and an increase of leaf nitrogen content for $\mathrm{P} 2$ and $\mathrm{P} 3$ provenance seedlings (Tab. VII). 
Table III. Effect of ectomycorrhizal inoculation and/or Bradyrhizobium Aust 13C on leaf mineral content after 5-month culture.

\begin{tabular}{|c|c|c|c|c|}
\hline Provenances & Treatments & $\mathrm{N}$ (mg/plant) & $\mathrm{P}(\mu \mathrm{g} /$ plant $)$ & $\mathrm{K}(\mu \mathrm{g} /$ plant $)$ \\
\hline \multirow[t]{4}{*}{$\overline{\mathrm{P} 1}$} & Not inoculated & $18.7 \mathrm{a}^{1}$ & $569.5 \mathrm{a}$ & $9809.7 \mathrm{a}$ \\
\hline & Aust $13 \mathrm{C}$ & $27.7 \mathrm{a}$ & $710.5 \mathrm{a}$ & $13908.1 \mathrm{a}$ \\
\hline & P. tinctorius & $53.6 \mathrm{~b}$ & $1743.6 \mathrm{~b}$ & 38196.7 b \\
\hline & P. tinctorius + Aust $13 \mathrm{C}$ & $66.6 \mathrm{c}$ & $2214.1 \mathrm{c}$ & $45603.4 \mathrm{~b}$ \\
\hline \multirow[t]{4}{*}{$\mathrm{P} 2$} & Not inoculated & $9.0 \mathrm{a}$ & $213.2 \mathrm{a}$ & $5631.2 \mathrm{a}$ \\
\hline & Aust 13C & $21.1 \mathrm{~b}$ & $419.3 \mathrm{a}$ & $12741.1 \mathrm{a}$ \\
\hline & P. tinctorius & $39.2 \mathrm{c}$ & $2034.4 \mathrm{~b}$ & $33167.3 \mathrm{~b}$ \\
\hline & P. tinctorius + Aust $13 \mathrm{C}$ & $81.3 \mathrm{~d}$ & $3108.1 \mathrm{c}$ & $55742.1 \mathrm{c}$ \\
\hline \multirow[t]{4}{*}{ P3 } & Not inoculated & $12.9 \mathrm{a}$ & $388.1 \mathrm{a}$ & $8252.1 \mathrm{a}$ \\
\hline & Aust $13 \mathrm{C}$ & $34.6 \mathrm{~b}$ & $930.0 \mathrm{~b}$ & $17414.2 \mathrm{~b}$ \\
\hline & P. tinctorius & $42.9 \mathrm{~b}$ & $1564.3 \mathrm{c}$ & $34768.3 \mathrm{c}$ \\
\hline & P. tinctorius + Aust $13 \mathrm{C}$ & $60.5 \mathrm{c}$ & $2263.4 \mathrm{~d}$ & $42606.2 \mathrm{~d}$ \\
\hline
\end{tabular}

${ }^{1}$ For each provenance, data in the same column followed by the same letter are not significantly different according to the one way analysis of variance $(P<0.05)$.

Table IV. Effect of the rhizobial and/or endomycorrhizal inoculations on plant growth of A. crassicarpa provenances after 5-month culture.

\begin{tabular}{|c|c|c|c|c|}
\hline Provenances & Treatments & Shoot Biomass (mg dry weight) & Root biomass (mg dry weight) & Total biomass (mg dry weight) \\
\hline \multirow[t]{4}{*}{ P1 } & Not inoculated & $167 \mathrm{a}^{1}$ & $10 \mathrm{a}$ & $177 \mathrm{a}$ \\
\hline & Aust $13 \mathrm{C}$ & $300 \mathrm{a}$ & $30 \mathrm{a}$ & $330 \mathrm{a}$ \\
\hline & G. intraradices & $3056 \mathrm{c}$ & $778 \mathrm{c}$ & $3833 \mathrm{c}$ \\
\hline & G. intraradices + Aust 13C & $2067 \mathrm{~b}$ & $411 \mathrm{~b}$ & $2478 \mathrm{~b}$ \\
\hline \multirow[t]{4}{*}{$\mathrm{P} 2$} & Not inoculated & $189 \mathrm{a}$ & $23 \mathrm{a}$ & $212 \mathrm{a}$ \\
\hline & Aust 13C & 356 a & $67 \mathrm{a}$ & $422 \mathrm{a}$ \\
\hline & G. intraradices & $2411 \mathrm{~b}$ & $578 \mathrm{c}$ & $2989 \mathrm{~b}$ \\
\hline & G. intraradices + Aust 13C & $2333 \mathrm{~b}$ & $422 \mathrm{~b}$ & $2756 \mathrm{~b}$ \\
\hline \multirow[t]{4}{*}{ P3 } & Not inoculated & $100 \mathrm{a}$ & $44 \mathrm{a}$ & $144 \mathrm{a}$ \\
\hline & Aust $13 \mathrm{C}$ & $1100 \mathrm{~b}$ & $256 \mathrm{~b}$ & $1356 \mathrm{~b}$ \\
\hline & G. intraradices & $1989 \mathrm{c}$ & $411 \mathrm{c}$ & $2400 \mathrm{c}$ \\
\hline & G. intraradices + Aust $13 \mathrm{C}$ & $1844 \mathrm{c}$ & $289 \mathrm{bc}$ & $2133 c$ \\
\hline
\end{tabular}

${ }^{1}$ For each provenance, data in the same column followed by the same letter are not significantly different according to the one way analysis of variance $(P<0.05)$.

\section{DISCUSSION}

From this research work, two main conclusions can be done: (i) ectomycorrhizal and AM fungal symbiosis clearly benefit to the growth of $A$. crassicarpa provenances, and (ii) these fungal symbioses greatly improve rhizobial nodulation process.

Our results demonstrated the effectiveness of ectomycorrhizal and endomycorrhizal symbiosis in improving the growth of all A. crassicarpa provenances. It is in accordance with results obtained with $A$. holoserice and $A$. mangium inoculated with Pisolithus isolates ( $P$. albus and P. tinctorius strains) or Scleroderma isolates ( $S$. dictyosporum and $S$. verrucosum strains) [12-14]. The results of the present study suggest clearly that $A$. crassicarpa is also highly dependent to the mycorrhizal symbiosis and that this mycorrhizal dependency is not related to their provenance. As A. crassicarpa is usually considered to be suitable for planting on degraded areas in the tropics and on a wide range of infertile soils, the inoculation of selected mycorrhizal symbionts should be useful in rehabilitation programs to restore sustainable ecosystems and for private companies who want to set up new industrial plantations of $A$. crassicarpa.

The symbiotic efficiency of the Bradyrhizobium strain Aust13C with A. mangium has been largely demonstrated through several studies carried out in the field [16-18]. This strain was also able to form nodules on the root system of $A$. crassicarpa and to improve its growth (Antoine Galiana, personal communication). According to these results, we decided to use it for inoculating A. crassicarpa in both experiments presented 
Table V. Effect of microbial inoculation on endomycorrhizal establishment and on rhizobial symbiosis after 5-month culture.

\begin{tabular}{|c|c|c|c|c|}
\hline Provenances & Treatments & Endomycorrhizal colonization (\%) & Number of nodules per plant & Nodule dry weight (mg/plant) \\
\hline \multirow[t]{4}{*}{ P1 } & Not inoculated & $0 \mathrm{a}^{1}$ & $0 \mathrm{a}$ & $0 \mathrm{a}$ \\
\hline & Aust 13C & $0 \mathrm{a}$ & $0 \mathrm{a}$ & $0 \mathrm{a}$ \\
\hline & G. intraradices & $34.3 \mathrm{~b}$ & $13 \mathrm{~b}$ & $41 \mathrm{~b}$ \\
\hline & G. intraradices + Aust 13C & $45.2 \mathrm{~b}$ & $17.8 \mathrm{~b}$ & $47 \mathrm{~b}$ \\
\hline \multirow[t]{4}{*}{$\mathrm{P} 2$} & Not inoculated & $0 \mathrm{a}$ & $0 \mathrm{a}$ & $0 \mathrm{a}$ \\
\hline & Aust $13 \mathrm{C}$ & $0 \mathrm{a}$ & $0 \mathrm{a}$ & $0 \mathrm{a}$ \\
\hline & G. intraradices & $60.8 \mathrm{~b}$ & $17 \mathrm{~b}$ & $35 \mathrm{~b}$ \\
\hline & G. intraradices + Aust 13C & $55.2 \mathrm{~b}$ & $25.6 \mathrm{~b}$ & $89 \mathrm{c}$ \\
\hline \multirow[t]{4}{*}{ P3 } & Not inoculated & $0 \mathrm{a}$ & $0 \mathrm{a}$ & $0 \mathrm{a}$ \\
\hline & Aust $13 \mathrm{C}$ & $0 \mathrm{a}$ & $0 \mathrm{a}$ & $0 \mathrm{a}$ \\
\hline & G. intraradices & $61.7 \mathrm{~b}$ & 9.9 a & $46 \mathrm{~b}$ \\
\hline & G. intraradices + Aust $13 \mathrm{C}$ & $57.2 \mathrm{~b}$ & $25.4 \mathrm{~b}$ & $55 \mathrm{~b}$ \\
\hline
\end{tabular}

${ }^{1}$ For each provenance, data in the same column followed by the same letter are not significantly different according to the one way analysis of variance $(P<0.05)$.

Table VI. Effect of endomycorrhizal inoculation and/or Bradyrhizobium Aust13C on leaf mineral content after 5-month culture.

\begin{tabular}{|c|c|c|c|c|}
\hline Provenances & Treatments & $\mathrm{N}$ (mg/plant) & $\mathrm{P}(\mu \mathrm{g} /$ plant $)$ & $\mathrm{K}(\mu \mathrm{g} /$ plant $)$ \\
\hline \multirow[t]{4}{*}{$\mathrm{P} 1$} & Not inoculated & $2.1 \mathrm{a}^{1}$ & $38.3 \mathrm{a}$ & $1201.7 \mathrm{a}$ \\
\hline & Aust $13 \mathrm{C}$ & $5.2 \mathrm{a}$ & $78.1 \mathrm{a}$ & $2282.0 \mathrm{a}$ \\
\hline & G. intraradices & $36.3 \mathrm{~b}$ & $1619.4 \mathrm{c}$ & $25788.9 \mathrm{c}$ \\
\hline & G. intraradices + Aust $13 \mathrm{C}$ & $34.1 \mathrm{~b}$ & $992.1 \mathrm{~b}$ & $19261.3 \mathrm{~b}$ \\
\hline \multirow[t]{4}{*}{ P2 } & Not inoculated & $2.8 \mathrm{a}$ & $37.8 \mathrm{a}$ & $1518.7 \mathrm{a}$ \\
\hline & Aust 13C & $5.9 \mathrm{a}$ & $106.7 \mathrm{a}$ & $3349.3 \mathrm{a}$ \\
\hline & G. intraradices & $32.5 \mathrm{~b}$ & $1615.4 \mathrm{~b}$ & $22568.0 \mathrm{~b}$ \\
\hline & G. intraradices + Aust 13C & $44.9 \mathrm{c}$ & $1703.3 \mathrm{~b}$ & $24266.7 \mathrm{~b}$ \\
\hline \multirow[t]{4}{*}{ P3 } & Not inoculated & $2.1 \mathrm{a}$ & $37.3 \mathrm{a}$ & $1114.7 \mathrm{a}$ \\
\hline & Aust $13 \mathrm{C}$ & $17.7 \mathrm{~b}$ & $352.1 \mathrm{~b}$ & $12035.7 \mathrm{~b}$ \\
\hline & G. intraradices & $26.5 \mathrm{c}$ & $1113.8 \mathrm{c}$ & $19172.9 \mathrm{c}$ \\
\hline & G. intraradices + Aust $13 \mathrm{C}$ & $35.1 \mathrm{~d}$ & $1198.9 \mathrm{c}$ & $20344.2 \mathrm{c}$ \\
\hline
\end{tabular}

${ }^{1}$ For each provenance, data in the same column followed by the same letter are not significantly different according to the one way analysis of variance $(P<0.05)$.

in this work. Results obtained confirmed those already obtained, especially in the first experiment carried out during the hot season. A. crassicrapa is described as being originated from warm and hot humid and sub-humid areas. So it means that this species is more adapted to hot than cold temperatures. This characteristic could explain why $A$.crassicarpa seedlings inoculated with Aust $13 \mathrm{C}$ and grew during the cold season were poorly nodulated compare to seedlings of the same treatment of the other experiment carried out during the hot season. Regarding the presence of nodules on the root system of noninoculated plants, we know that usually, autoclaved soils are not totally sterilized. So it means that when the environmental conditions are favourable, we can observe a nodulation of these plants, nodulation usually induced by native rhizobia which persist in the soil. It may be that we observed in the experiment carried out during the hot season. We could assume also that the nodules formed on the non-inoculated plants were preferentially occupied by the strain Aust $13 \mathrm{C}$ rather than by the native rhizobia. No nodules analyses were done. It will impossible to conclude on this. But the Aust $13 \mathrm{c}$ strain is very competitive for nodulating the compatible host plant. For exemple in Madagascar, Prin et al. [32] demonstrated in an inoculation field 
trial that the progressive reduction of the positive effect of Aust13C inoculation on A. mangium tree growth after field transplanting was not due to a progressive disappearance of the introduced strain, but on the contrary, was related to the widening spreading of Aust $13 \mathrm{c}$ in all the plots. These authors concluded on the higher competitiveness of Aust13c over the local strains naturally present on the soil. It was not the case in our first experiment because for the three provenances, seedlings inoculated with Aust13C produced more significant biomass than the not inoculated plants (Tab. II). It suggests that the plants control and those inoculated with Pisolithus tinctorius only were essentially nodulated by native rhizobia. This assumption is strengthened by the fact that $A$. crassicarpa is not highly specific for nodulating with rhizobia [8]. It can easily nodulate with native rhizobia. It is interesting to note that the ectomycorrhizal fungus stimulated the nodulation of the not inoculated plants with Aust 13C. It seems to correspond to a synergistic effect. This synergistic effect on the plant growth was also recorded when $P$. tinctorius and the bradyrhizobial strain Aust 13C were co-inoculated. This ectomycorrhizal fungal symbiosis increased root growth and could facilitate rhizobial colonization and infection. Moreover, it is well established that nodule formation and functioning are dependant on mycorrhizal formation through the improvement of $\mathrm{P}$ uptake which enhances nodulation and $\mathrm{N}_{2}$ fixation $[7,32]$. It is also well demonstrated that the root exudation is modified both qualitatively and quantitatively by the presence of an active mycorrhizal symbiosis [2, 23, 37]. These changes could increase the rhizobial multiplication in the mycorrhizosphere.

Hardwood et al. [21] demonstrated that the Papua New Guinea provenances grew faster than the other provenances. Our results confirm these data because for both experiments, the more important total biomasses were obtained with the provenances P1 and P2 from Papua New Guinea and not with P3 from Madagascar. However, no significant difference of nodulation and mycorrhization were observed between three provenances.

In conclusion, our results demonstrated that mycorrhizal associated to rhizobial symbiosis could be a great interest in reafforestation programs where $A$. crassicarpa are used to rehabilitate degraded areas.

Acknowledgments: This work was funded by IRD and the Forestry Department of CIRAD. The authors are grateful to Jacques Biagui, Leon Biagui and Lamine $\mathrm{Ba}$ for their technical assistance in the nursery.

\section{REFERENCES}

[1] Bâ A.M., Dalpé Y., Guissou T., Les glomales d'Acacia holosericea et d'Acacia mangium, Bois, For. Trop. 250 (1996) 5-18.

[2] Barea J.M., Azcon R., Azco-Aguilar C., Vesicular-arbuscular mycorrhizal fungi in nitrogen-fixing systems, in: Norris J.R., Read D., Varma A. (Eds.), Techniques for the study of Mycorrhizae, Methods in Microbiology, Vol. 24, Academic Press, London, 1992, pp. 391-416.

[3] Brundrett M.C., Piche Y., Peterson R.L., A developmental study of the early stages in vesicular-arbuscular mycorrhizal formation, Can. J. Bot. 63 (1985) 184-194.
[4] Cornet F., Diem H.G., Étude comparative de l'efficacité des souches de Rhizobium d'acacia isolées de sols du Sénégal et effet de la double symbiose Rhizobium - Glomus mosseae sur la croissance de Acacia holosericea et A. raddiana, Bois For. Trop. 198 (1982) 3-15.

[5] Cossalter C., Introducing Australian acacias in dry, tropical Africa, in: Turnbull J.W. (Ed.), Australian acacias in developing countries, Proc. international Workshop at the Forestry Training Centre, Gympie, Australia, ACIAR: Camberra, 1986, pp. 118-122.

[6] Diouf D., Forestier S., Neyra M., Lesueur D., Optimisation of inoculation of Leucaena leucocephala and Acacia mangium with rhizobium under greenhouse conditions, Ann. For. Sci. 60 (2003) 379-384.

[7] De la Cruz R.E., Manalo M.Q., Aggangan N.S., Tambalo J.D., Growth of three legume trees inoculated with VA mycorrhizal fungi and Rhizobium, Plant Soil 108 (1988) 111-115.

[8] Dommergues Y.R., Duhoux E., Diem H.G., Les arbres fixateurs d'azote : caracteristiques fondamentales et role dans l'amenagement des ecosystems mediterraneens et tropicaux, CIRAD (Montpellier), éditions Espaces 34 Montpellier, FAO Roma, IRD Paris, 1999, $500 \mathrm{p}$.

[9] Doran J.C., Turnbull J.W., Australian trees and shrubs: species for land rehabilitation and farm planting in the tropics, ACIAR Monogr. No. 24, Camberra, Australia, 1997, 384 p.

[10] Duponnois R., Bâ A.M., Growth stimulation of Acacia mangium Willd. by Pisolithus sp. in some Senegalese soils, For. Ecol. Manage. 119 (1999) 209-215.

[11] Duponnois R., Garbaye J., Techniques for controlled synthesis of the Douglas fir - Laccaria laccata ectomycorrhizal symbiosis, Ann. Sci. For. 48 (1991) 239-251.

[12] Duponnois R., Plenchette C., A mycorrhiza helper bacterium enhances ectomycorrhizal and endomycorrhizal symbiosis of Australian Acacia species, Mycorrhiza 13 (2003) 85-91.

[13] Duponnois R., Founoune H., Lesueur D., Influence of the controlled dual ectomycorrhizal and rhizobial symbiosis on the growth of Acacia mangium provenances, the indigenous symbiotic microflora and the structure of plant parasitic nematode communities, Geoderma 109 (2002) 85-102.

[14] Duponnois R., Founoune H., Lesueur D., Thioulouse J., Neyra M., Ectomycorrhization of six Acacia auriculiformis provenances from Australia, Papua New Guinea and Senegal in glasshouse conditions: effect on the plant growth and on the multiplication of plant parasitic nematodes, Aust. J. Exp. Agr. 40 (2000) 443-450.

[15] Founoune H., Duponnois R., Bâ A.M., El Bouami F., Influence of dual arbuscular endomycorrhizal/ectomycorrhizal symbiosis on the growth of Acacia holosericea (A. Cunn. ex G. Don) in glasshouse conditions, Ann. For. Sci. 59 (2002) 93-98.

[16] Galiana A., Balle P., N'Guessan Kanga A., Domenach A.M., Nitrogen fixation estimated by the ${ }^{15} \mathrm{~N}$ natural abundance method in Acacia mangium Willd. inoculated with Bradyrhizobium sp. and grown in silvicultural conditions, Soil Biol. Biochem. 34 (2002) 251-262.

[17] Galiana A., Chaumont J., Diem H.G., Dommergues Y.R., Nitrogen-fixing potential of Acacia mangium and Acacia auriculiformis seedlings inoculated with Bradyrhizobium and Rhizobium spp., Biol. Fert. Soils 9 (1990) 261-267.

[18] Galiana A., Gnahoua G.M., Chaumont J., Lesueur D., Prin Y., Mallet B., Improvement of nitrogen fixation in Acacia mangium through inoculation with rhizobium, Agroforest Syst. 40 (1998) 297-307.

[19] Giffard P.L., Les gommiers, essences de reboisement pour les régions sahéliennes, Bois For. Trop. 161 (1975) 3-20.

[20] Giffard P.L., L'arbre dans le paysage sénégalais. Sylviculture en zone tropicale sèche, Centre Technique Forestier Tropical, Dakar, Sénégal, 1974.

[21] Hardwood C.E., Haines M.W., Williams E.R., Early growth of Acacia crassicarpa in a seedling seed orchad at Melville Island, Australia, FAO Forest Genetic Resources Information 21 (1993) $46-53$. 
[22] John M.K., Colorimetric determination in soil and plant material with ascorbic acid, Soil Sci. 68 (1970) 171-177.

[23] Kothari S.K., Marshner H., Römheld V., Effect of a vesiculararbuscular mycorrhizal fungus and rhizosphere microorganisms on manganese reduction in the rhizosphere and manganese concentrations in maize (Zea mays L.), New Phytol. 117 (1991) 649-655.

[24] Lesueur D., Yattara I., Louppe D., Sougoufara B., Gnahoua G.M., Ouattara N., Kolou O., Yossi H., Mallet B., Fixation symbiotique de l'azote au sein de jachères améliorées à Acacia mangium et Acacia auriculiformis en Côte d'Ivoire, au Mali et au Sénégal, in: Floret C., Pontanier R. (Eds.), La Jachère en Afrique Tropicale, Paris, Jonh Libbey Eurotext, 2000, pp. 664-674.

[25] Marx D.H., The influence of ectotropic mycorrhizal fungi on the resistance of pine roots to pathogenic infections. I. Antagonism of mycorrhizal fungi to root pathogenic fungi and soil bacteria, Phytopathology 59 (1969) 153-163.

[26] Midgley S., Acacia crassicarpa: a tree in the domestication fast lane, Austral. Tree Res. News 6 (2000) 1-3.

[27] Näsholm T., Ekblad A., Nordi A., Giesler R., Högberg M., Högberg P., Boreal forest plants take up organic nitrogen, Nature 392 (1998) 914-916.

[28] Pedley L., Australian acacia: taxonomy and phytogeography, in: Turnbull J.W. (Ed.), Australian acacias in developing countries, Proc. international Workshop at the Forestry Training Centre, Gympie, Australia, ACIAR, Camberra, 1986, pp. 11-16.

[29] Peoples M.B., Herridge D.F., Ladha J.K., Biological nitrogen fixation: an efficient source of nitrogen for sustainable agriculture? Plant Soil 174 (1995) 3-18.
[30] Phillips J.M., Hayman D.S., Improved procedures for clearing roots and staining parasitic and vesicular-arbuscular mycorrhizal fungi for rapid assessment of infection, Trans. Brit. Mycol. Soc. 55 (1970) $158-161$.

[31] Plenchette C., Declerck S., Diop T., Strullu D.G., Infectivity of monoaxenic subcultures of the AM fungus Glomus versiforme associated with Ri-TDNA transformed root, Appl. Microbiol. Biotech. 46 (1996) 545-548.

[32] Prin Y., Galiana A., Le Roux C., Meleart B., Razafimaharo V., Ducousso M., Chaix G., Molecular tracing of Bradyrhizobium strains helps to correctly interpret Acacia mangium response to incoculation in a reforestation experiment in Madagascar, Biol. Fertil. Soils 37 (2003) 64-69.

[33] Reddell P., Warren R., Inoculation of acacia with mycorrhizal fungi: potential benefits, in: Turnbull J.W. (Ed.), Australian acacias in developing countries, ACIAR, Camberra, 1986, pp. 50-53.

[34] Sim B.L., Gan E., Performance of Acacia species on four sites of Sabah Forest Industries, in: Turnbull J.W. (Ed.), Advances in tropical acacia research, ACIAR Proc. No. 35, Camberra, 1986, pp. 45-54.

[35] Vincent J.M., A manual for the practical study of root-nodule bacteria. International Biological programme, Vol. 15, Blackwell, Oxford, 1970.

[36] Visaratana T., Biomass studies in Thailand, ACIAR For. Newslett. 8 (1989) $1-7$.

[37] Waschkies C., Schropp A., Marschner H., Relations between grapevine replant disease and root colonization of grapevine (Vitis sp.) by fluorescent pseudomonads and endomycorrhizal fungi, Plant Soil 162 (1994) 219-227. 